\title{
Balancing livestock production and wildlife conservation in and around southern
} Africa's transfrontier conservation areas

\author{
G R Thomson ${ }^{1}$, M-L Penrith², M W Atkinson ${ }^{3}$, S J Atkinson ${ }^{4}$, D Cassidy ${ }^{5}$ \& S A Osofsky ${ }^{4}$ \\ Correspondence: Gavin Thomson, P O Box 1607, Brooklyn Square, Pretoria 0075, South Africa
}

Tel: +27129932779 or +27823366088

E-mail: gavin@tadscientific.co.za

\begin{abstract}
Biodiversity conservation, of which the transfrontier conservation area movement is an integral part, and more effective livestock production/trade are pivotal to future rural development in southern Africa. For that reason it is imperative to effectively ameliorate the obstacles that have impeded progress towards the co-existence of these two imperatives for more than half a century. Transboundary animal diseases, foot and mouth disease in particular, have been and continue to be the most important of these obstacles. Fortunately, new developments in international sanitary standards applicable to trade in commodities and products derived from animals are beginning to make a solution possible. However, while progress in principle has been achieved, practical implementation remains problematic for technical reasons, exacerbated by inconsistent attitudes towards acceptance of nontraditional international trade standards. This paper describes the background to this situation, progress that has been achieved in the recent past and remaining difficulties that need to be overcome to advance towards achievement of balanced rural development in southern Africa.
\end{abstract}

Keywords: transboundary animal diseases, livestock production, biodiversity conservation, transfrontier conservation areas

\section{Introduction}

To advance the cause of conservation in southern and parts of East Africa, 14 terrestrial transfrontier conservation areas $\left(\mathrm{TFCAs}^{6}\right)$ have been or are being established, covering at

\footnotetext{
${ }^{1}$ P O Box 1607, Brooklyn Square, Pretoria 0075, South Africa

2 PostNet Suite 439, P Bag X15, Menlo Park 0102, Pretoria. South Africa

${ }^{3}$ Wildlife Health Program, Wildlife Conservation Society, P O Box 402999, Gaborone. Botswana.

${ }^{4}$ Wildlife Health Program, Wildlife Conservation Society, 2300 Southern Boulevard, Bronx, NY 10460. USA

${ }^{5}$ Deceased
} 
least $750000 \mathrm{~km}^{2}$, i.e. an area comparable in size to the surface areas of Germany, Italy and Portugal combined (Cumming, 2011). TFCAs are intended as multiple land-use areas with an emphasis on biodiversity conservation and mobilisation of the economic benefits of nature-based tourism and related activities (Cumming, 2008).

The locations of the TFCAs (Fig. 1) have widely distributed miombo woodlands that are species-rich as well as being highly threatened in respect of that richness (UNEP, 2011). Furthermore, it is common knowledge that eastern and southern Africa have the widest diversity and number of large ungulates and associated predators on earth. These populations are not only a priceless global asset but are vital to international tourism, an important income generator for many in the region. Although precise data in that respect are lacking, by 2000 , the contribution of nature-based tourism to southern African regional GDP was estimated to have reached a level close to the combined contributions of agriculture (including livestock), fisheries and forestry (Scholes and Biggs, 2004).

Livestock production has traditionally been considered the most important element of rural development in the drier western half of southern Africa where arable agriculture is problematic. Consistent with that view have been ongoing efforts, dating from colonial times, aimed at commercialisation of livestock production and securing access to high-value European markets, particularly for beef. Furthermore, rural communities in southern Africa are predominantly members of cultures for which livestock, especially cattle, are important. At least 10 million poor people in the SADC (Southern African Development Community) region are entirely dependent on livestock (roughly $4.3 \%$ of the total mainland population of the region, numbering about 234.5 million). These people occupy territory approximately 2.87 million $\mathrm{km}^{2}$ in extent (close to the size of India), $75 \%$ of which is arid or semi-arid (Thornton et al., 2003). Many more people, perhaps exceeding 100 million, are partially dependent on livestock (Thornton et al., 2003), which implies that more than $40 \%$ of the SADC's human population is to some extent dependent on livestock. Population growth in the SADC region is around $1.6-2 \%$ per annum so figures published in 2003 will have increased concomitantly.

A key constraint to successful integration of wildlife conservation and livestock production systems in southern Africa concerns the abundance and range of infectious agents that coevolved with wildlife (Bengis et al., 2004). Some of these are able to cause disease in livestock (e.g. SAT serotypes of foot and mouth disease [FMD] virus, wildebeest-associated malignant catarrhal fever virus, some Theileria spp., African swine fever virus) and even

\footnotetext{
6 The area or component of a large ecological region that straddles the boundaries of two or more countries, encompassing one or more protected areas as well as multiple resource use areas
} 


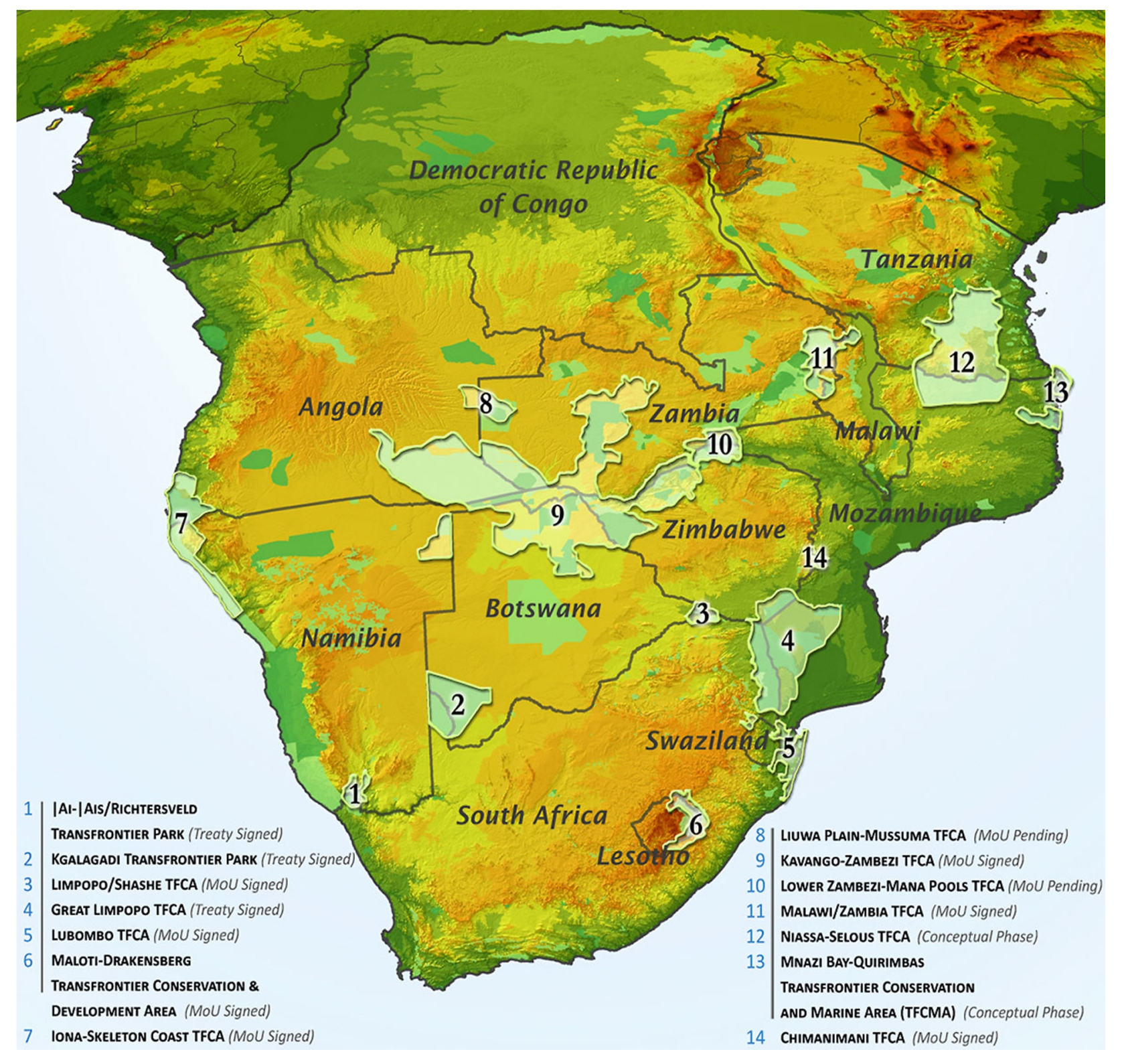

\section{Figure 1}

Location of 14 established or planned transfrontier conservation areas (TFCAs) in southern Africa (www.peaceparks.org) 
people (Rift Valley fever [RVF] virus, the viverrid biotype of rabies virus, and certain trypanosomes). While innovative ways of managing some of these diseases have been developed, especially in South Africa, through vaccine development in the mid-20 ${ }^{\text {th }}$ Century, effective control of most of them has historically focused on separation of wildlife and livestock to prevent transmission of these infections. This concept was applied later to national and international policies and trade regulations/standards for animals and animal products that have largely survived to the present. The need to separate livestock from wildlife in order to create zones free from diseases that constrained livestock production and market access such as FMD and trypanosomosis resulted in extensive fencing systems, particularly in Botswana, Zimbabwe, Namibia and South Africa. Although the fences largely achieved their objective some have had devastating environmental effects which, although documented and publicised, were presumably considered acceptable by the relevant authorities because their priority was livestock production rather than biodiversity conservation (Osofsky et al., 2008; Ferguson and Hanks, 2010; Cumming and Atkinson, 2012). Despite these measures, access to markets for livestock and livestock products in the region continues to be constrained by FMD while traditional methods of control have in the last 10-12 years proven less effective than formerly (University of Pretoria/Agricultural Research Council, 2012; unpublished report, University of Pretoria, 2012 ${ }^{7}$ ) (Fig. 2). This situation has contributed to under-investment in livestock agriculture with inevitable deficiencies in productive capacity and efficiency (Rich, 2009; Rich and Perry, 2011). As a consequence, southern Africa faces ongoing loss of biodiversity as well as limited access to high value markets for animal products with little prospect of ever being able to compete effectively in those markets.

We contend, as have others, that while the TFCA movement is vital for biodiversity conservation and rural development in southern Africa, the sustainability of the initiative will only be assured if it accommodates livestock agriculture in and around the largest TFCAs where livestock are indispensable to livelihood generation for indigenous people (Osofsky et al., 2005). Livestock owners in these locations need to be in a position to generate a reasonable return on their most valuable personal resource in order to reduce unacceptable levels of poverty which cannot be addressed by tourism alone. For that to happen, TADs management strategies need to be structured so that they are appropriate for both biodiversity conservation and livestock production.

\footnotetext{
${ }^{7}$ University of Pretoria, 2012: Broadening access to international and regional markets for southern Africa's livestock producers. Proceedings of a workshop held at the Faculty of Veterinary Science, University of Pretoria, 27-28 November 2012. Available from: rene.perridge@up.ac.za.
} 


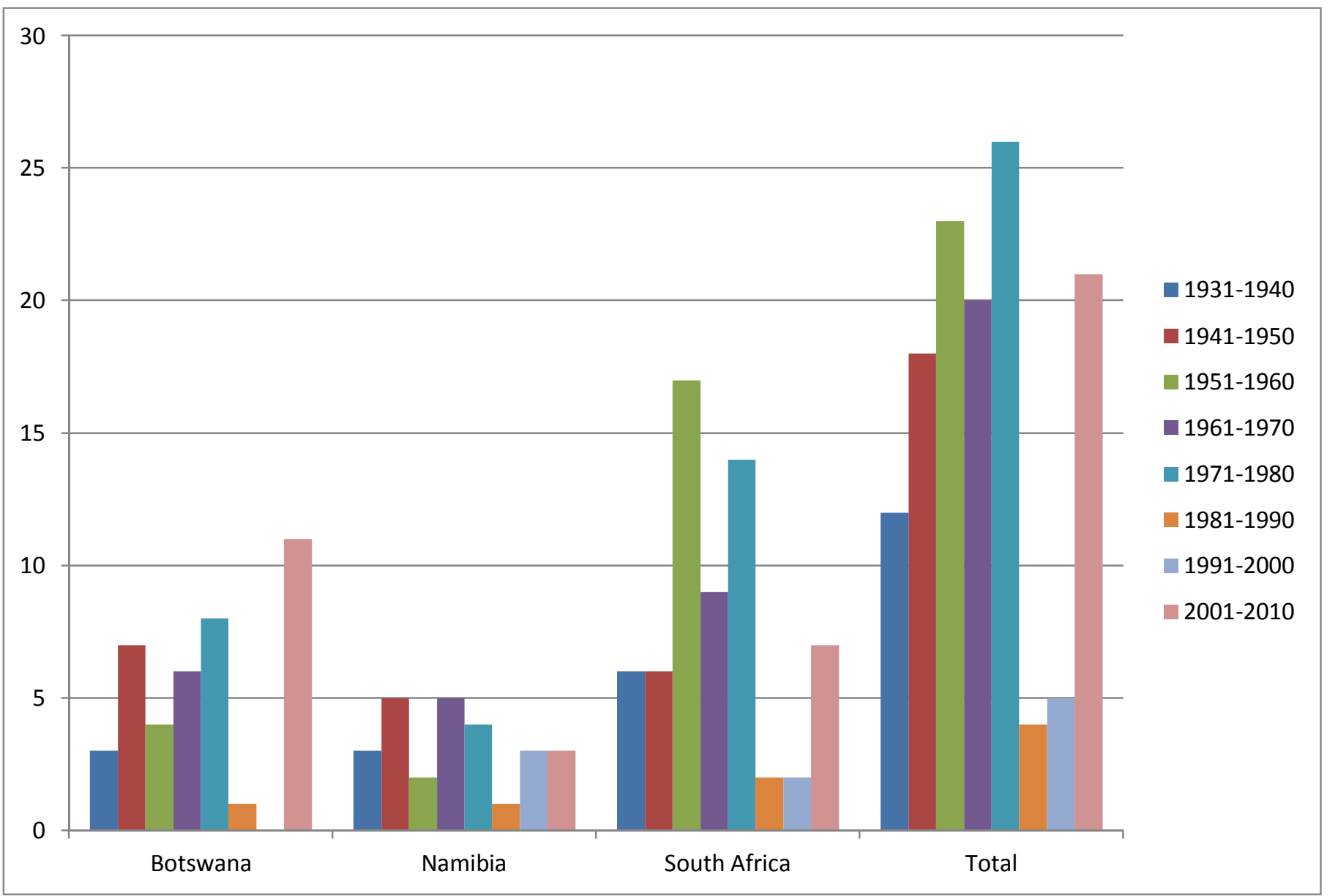

Figure 2

Occurrence of SAT serotype outbreaks of FMD per decade in three southern African countries between 1931-2010 


\section{Biodiversity, conservation management and poverty reduction}

Perturbations in the environment of free-living animals, whether anthropogenic or not, can have complex effects on gene flows and biodiversity (Crispo et al., 2011). Severe disruption can lead to wildlife population fragmentation, isolation of sub-populations and loss of genetic diversity, thereby rendering populations more prone to population crashes and extinction events than would otherwise be the case. The loss of biodiversity that results as a consequence is increasingly recognised as a major weakness of creating "conservation islands' in the form of national parks and protected areas as has been the trend in southern Africa for decades.

Effective long-term conservation management is thus generally dependent upon maintaining or re-establishing gene flows between wildlife populations that were formerly sympatric.

Roe et al. (2011) have argued through ten frequently asked questions that biodiversity and poverty reduction are to some extent interdependent, mainly related to ensuring the availability of a variety of natural resources for poor people to exploit. However, they concede that trade-offs are often necessary. For that reason, the better factors involved in such interactions are understood the more effectively they can be managed.

\section{Transboundary animal disease trends associated with transfrontier conservation areas in southern Africa}

There are many known animal infections, some zoonotic, that have the potential to cause major direct or indirect impacts in and around southern African TFCAs: examples are FMD, RVF, trypanosomosis, Newcastle disease (NCD), rabies, anthrax, lumpy skin disease (LSD), wildebeest-associated malignant catarrhal fever (MCF), contagious bovine pleuropneumonia (CBPP), Theileria spp. infections, African swine fever (ASF), African horse sickness (AHS), bluetongue (BT), peste des petits ruminants (PPR), Crimean-Congo haemorrhagic fever, avian influenza, bovine tuberculosis and brucellosis (Alexander et al., 2004; Coetzer and Tustin, 2004; Gauthier-Clerc et al., 2007; Heffernan, 2009; Cumming et al., 2011).

A recent study has assessed the occurrence, distribution and effects of most of these diseases in the five countries (Angola, Botswana, Namibia, Zambia and Zimbabwe) that contribute to the Kavango Zambezi (KAZA) TFCA, by far the largest TFCA in southern Africa (Penrith and Thomson, 2012). Among the conclusions of the study were:

- Information on major TADs is incomplete for most countries in the SADC region;

- Diseases of particular concern for the five countries are FMD, CBPP (although this disease does not occur in wildlife species, lowering of fences between countries of 
different disease status e.g. in the KAZA TFCA could facilitate cross-border movement of cattle), bovine brucellosis, bovine tuberculosis and rabies;

- PPR presents a new and evolving threat to the southern African region (the same is probably the case for contagious caprine pleuropneumonia);

- Disease outbreaks, in particular FMD and RVF, appear to be increasing in the region;

- FMD's impact is predominantly indirect through its effect on trade.

In other southern African TFCAs with large wildlife populations the animal infection/disease situation is likely to be similar to that of the KAZA TFCA with the exception of CBPP because this disease does not occur in the majority of southern African countries and does not affect wildlife.

A feature of FMD in southern and East Africa that distinguishes it from the disease elsewhere in the world is the occurrence of SAT serotypes that almost certainly co-evolved in sub-Saharan Africa with African buffalo (Syncerus caffer); healthy buffalo populations maintain these infections and may spread them to other cloven-hoofed animals, both freeliving and domestic, with which they come into close contact (Thomson et al., 2003). Until recently, most southern African countries controlled SAT infections effectively by preventing infection of cattle through vaccination of cattle populations at high risk, movement control (reliant on extensive fencing systems) and other zoo-sanitary measures. However, in the last decade, after a period of 20 years when FMD control appeared to be increasingly effective, there has been resurgence in the occurrence of FMD outbreaks, at least in countries for which reliable data are available (Fig. 2; Thobokwe et al., 2010; University of Pretoria/Agricultural Research Council, 2011). Most of these SAT serotype outbreaks have occurred in and around the KAZA TFCA where perhaps 1.5 million people and their livestock are resident (Fig. 3).

The reason for this upsurge in the FMD problem is probably multi-faceted, including factors such as poor performance of current vaccination programmes (SADC, 2010: Part $2^{8}$ of the final report on the European Union-funded SADC FMD Project, GRM International), increasing populations of cattle and buffalo in and around some TFCAs such as KAZA (Chase, 2009), indiscriminate destruction of fences of all types in Zimbabwe as a result of the land reform process there, and possible declining efficacy of veterinary control generally. Lack of incentives for cattle producers to become involved in FMD control and the escalating costs of FMD control in the face of the global financial down-turn are other likely factors. Whatever the cause, the result has been that Zimbabwe, South Africa and Botswana

\footnotetext{
${ }^{8}$ Vaccination against SAT-serotypes of foot and mouth disease (FMD) in the SADC Region: Are currently available vaccines effective?
} 


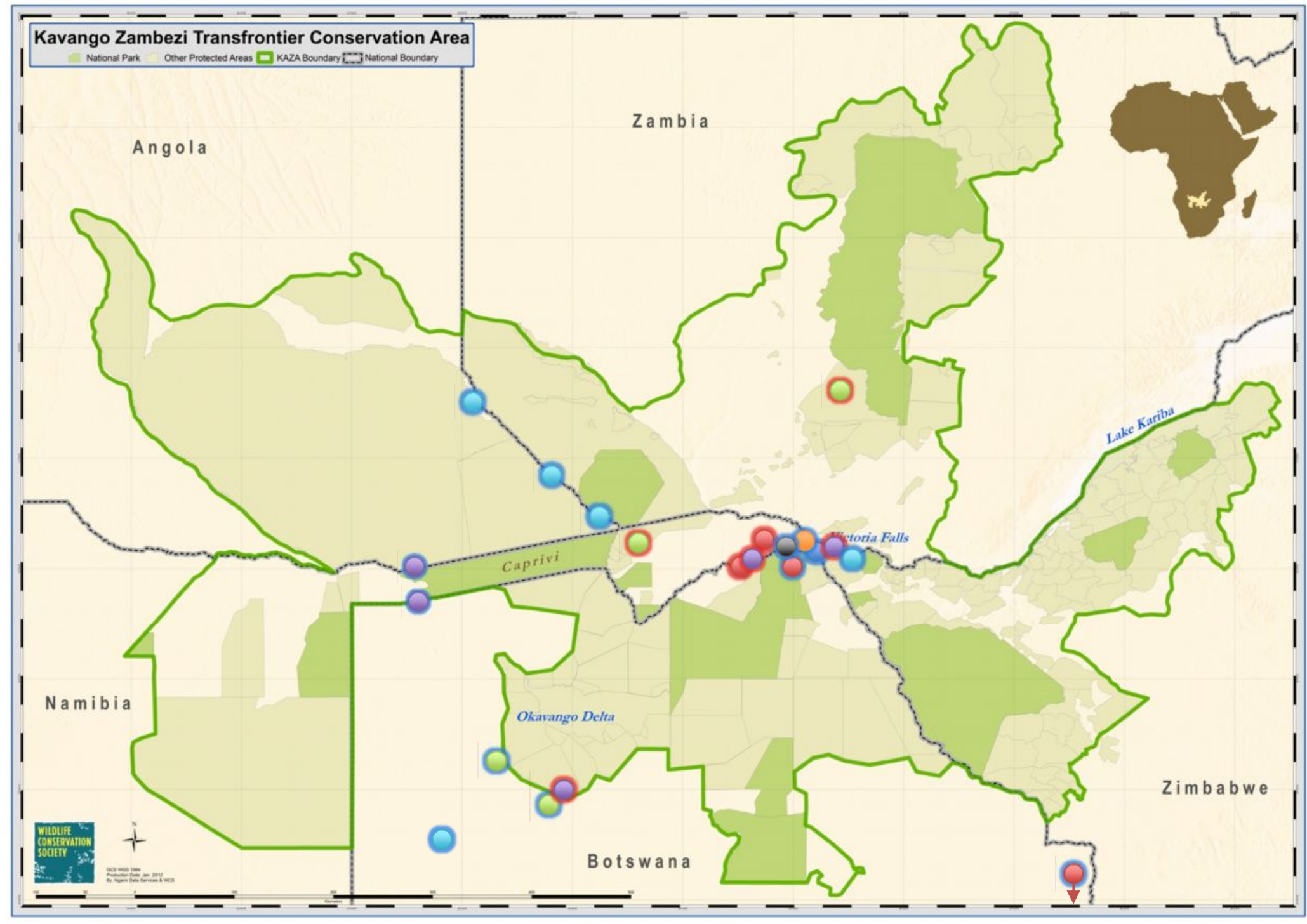

SAT 1

SAT 2

TFCA

$\sim$ Boundary

Fig 3.

Initial location of foot and mouth disease outbreaks in and around the Kavango Zambezi TFCA: 2005-2011 
(countries with traditionally excellent FMD control) have either temporarily or more enduringly lost access to foreign markets for livestock-based commodities and products (beef and wool particularly) due to outbreaks of TADs, especially FMD. South Africa, for example, is claimed to be losing R 4 billion (about US $\$ 500$ million) annually since loss of recognition of its FMD-free zone constrained meat product exports (Business Day [South Africa], 2011/10/06). Similarly, the Botswana Meat Commission (BMC) operated at a P 401 million (about US \$ 51 million) deficit over the 2009-2011 financial years and projects a further P 77 million deficit for 2012 (New Era, Namibia, 2012/06/20). In the case of Botswana this situation is not entirely due to animal disease; problems associated with animal traceability and certification were also involved (European Commission, Directorate F, 2011).

The animal disease situation described above presents a growing problem in respect of market access. However, the corollary is: If impediments to international market access for livestock products from southern Africa were removed, would the region be able to compete successfully in respect of price, quality and other market demands? The answer to that is 'no' because, as explained below, current beef exporters in the region are becoming less competitive and, crucially, are reliant on tariff protection. This state of affairs is arguably primarily due to underinvestment and poor organisation of animal agriculture as well as lack of trade incentives (Cabrera et al., 2008). Investment in animal agriculture, as is the case for investment of any kind, is dependent on access to markets appropriate for generating profit, i.e. market access is a prerequisite for essential private sector investment. The bottom line is that current sanitary standards and trade conventions remain a major disincentive for potential investors in animal agriculture in southern Africa.

\section{Unintended but unfortunate consequences of geographically-based standards for management of animal disease trade risks}

Current geographically-based standards incorporated into the TAHC and adopted by most major importing nations, apart from their beneficial regulatory influence on international trade, can also have unfortunate indirect social, financial and environmental impacts. In southern and East Africa, these are to a major extent associated with some of the regions' most important remaining wildlife populations that have suffered drastic reductions in overall numbers and distribution over the past half century (Norton-Griffiths, 2005; Vidal, 2011).

In an attempt to introduce flexibility into the geographic approach, the OIE instituted the concept of disease-free zones (regions) within countries and, in South America and southern Africa, this has been applied over many decades to create large areas from which FMD viruses are excluded. 
Despite the adverse environmental impacts of some animal disease management practices (e.g. cordon fencing) and the trade standards on which they are based the desire/intention to achieve eradication of FMD in southern African countries with large wildlife populations using demonstrably failed methodologies continues. Global rinderpest eradication, officially recognised in 2011 (FAO, 2011b), is usually held up as a prototype for the benefits of the eradication approach. What is rarely mentioned is that special circumstances existed in the case of rinderpest that made its eradication feasible (Roeder, 2005), and that these circumstances exist for very few other TADs (Thomson, Penrith \& Fosgate, in preparation). Crucially, the assumption that diseases associated with wildlife in S-SA are eradicable, other than through extirpation of the wildlife, has not been supported by feasibility studies. The inevitable result, over many decades, has been subjugation of the interests of wildlife conservation and associated enterprises to those of livestock agriculture with the objective of creating zones free from FMD to promote export-driven expansion of livestock production (Scoones et al., 2010; Thomson et al., in preparation).

A major problem with disease-free zones (DFZs) is that to be effective and financially viable as export zones, they need to cover large tracts of land with clearly defined borders able to actively manage entry and exit into the zone of susceptible animals (including wildlife) and of materials that could transport the infection (Article 5.3.7, OIE, 2012a). Some of the fences used to protect DFZs, but not all, have had disastrous consequences for free-ranging wildlife that are well documented but these effects have hitherto essentially been disregarded by national animal health authorities because the benefits of fences have been perceived as providing overriding benefit to the common good (Ferguson \& Hanks, 2010; Scoones et al, 2010).

Geographic standards associated with the creation of infection-free zones for FMD (for which an accreditation system is provided by the OIE, together with three other diseases, namely contagious bovine pleuropneumonia, bovine spongiform encephalopathy and African horse sickness) have enabled access to high value beef markets for producers in some southern African countries (e.g. Botswana, Namibia, Swaziland and Zimbabwe). Some of these zones have subsequently lapsed. However, creation of FMD-free zones elsewhere in southern Africa has so far proven impractical or unachievable; no new officially recognized disease free zones have been established in the last 20 years although some, in Botswana for example, have been extended. One of the reasons is that DFZs create complex administrative and socio-economic difficulties resulting from large areas having to be continuously managed to maintain their status, including active maintenance of biosecurity-, surveillance- and traceability systems. 
The costs of such systems, including construction and maintenance of extensive fencing and quarantine facilities, are usually borne by the government concerned and therefore constitute an indirect subsidy to livestock farmers. It is usually impossible to measure these costs accurately because disaggregated budgets of government departments are unavailable in the public domain. Apart from the high cost of fencing systems protecting FMD-free zones, some fences have negative environmental impacts that are particularly severe in terms of the sustainability of wildlife conservation and associated tourism (Mbaiwa and Mbaiwa, 2006; Ferguson \& Hanks, 2010). The measures instituted to maintain the integrity of DFZs furthermore impact on non-livestock-owning people living in those areas who do not benefit from livestock and whose livelihood opportunities are constrained because they require land-uses that are precluded by sanitary measures instituted to enable beef exports. These people are, ironically, often the poorest of the poor.

\section{Trade standards related to animal diseases and their impact on biodiversity conservation and rural development}

The need to balance the ideal of free trade in agricultural products, especially food, while at the same time providing countries with a mechanism to protect the health and safety of their people and environments (animal and plant populations) resulted in the Agreement on the Application of Sanitary and Phyto-sanitary Measures (SPS Agreement) (http://www.wto.org/english/tratop e/sps e/spsagr e.htm). For developing countries, especially those in sub-Saharan Africa, the SPS Agreement, as a result of standards set by its international standard-setting bodies (ISSBs) and the way these standards are applied for managing animal health risks associated with trade, is currently the most vexing problem inhibiting investment aimed at expanding trade in livestock commodities and products.

The international organisations mandated by the WTO to provide the standards for the SPS Agreement in respect of food safety and trade in animal commodities and products as they are affected by animal diseases are:

- The World Organisation for Animal Health (OIE), an independent organisation based in Paris; standards to prevent the spread of animal diseases are contained in two codes, the Terrestrial Animal Health Code (TAHC) (http://www.oie.int/internationalstandard-setting/terrestrial-code/access-online/) and the Code for Aquatic Animals (http://www.oie.int/international-standard-setting/aquatic-code/access-online/). 
- The Codex Alimentarius Commission, which operates under the joint auspices of the World Health Organisation (WHO) and the Food and Agriculture Organisation (FAO), both agencies of the United Nations (UN), is responsible for standards to assure food safety of agricultural products. This Commission is based in the FAO headquarters in Rome and the standards it sets are contained in the "Codex Alimentarius" (www.codexalimentarius.net web/standard list.jsp).

Two major problems arise from these trade standards for animal disease control: (1) the impact of geographically based standards on biodiversity conservation and rural development, and (2) the lack of complementarity between the standards for food safety provided by the Codex Alimentarius and those for trade in livestock commodities provided by the OIE. The need to refer to two sets of standards based on different approaches adopted by the two ISSBs complicates trade in livestock commodities and products. As a result many countries tend to adopt the often higher European Union standards that are easier to access and that integrate standards for food safety and animal disease risk.

In respect of FMD, the TAHC provides standards for country freedom and free zones with and without vaccination, which can be officially recognised by the OIE (OIE, 2012a). Country freedom is clearly not attainable for most countries in the SADC region other than those that are oceanic islands. The reason is the wide distribution of African buffalo naturally infected with SAT serotypes of FMD virus. The establishment and maintenance of free zones entails strict separation of uninfected cloven-hoofed animals from potentially infected populations, usually achieved though fencing. The impacts of this approach on biodiversity conservation include interruption of migration routes for wildlife with reduced access to adequate grazing and water resulting in attrition of these populations due both to hunger and thirst and to traumatic contact with the fences (Mbaiwa and Mbaiwa, 2006; Osofsky et al., 2008; Ferguson and Hanks, 2010). Rural development in FMD-infected and protection zones is hampered by reduced market access and the reduced economic value of cloven-hoofed animals restricted to those zones (Thomson et al. 2004). Maintenance of FMD-free zones is conducted predominantly by governments (public sector), thereby providing a subsidy to animal agriculture. However, that public sector investment may not be justified by the benefits of export to high value markets because in recent times FMD-free zones are proving increasingly difficult to maintain (Scoones et al., 2010).

\section{Alternative approaches to geographical freedom for managing animal disease risks}

Although the Codex Alimentarius and the TAHC address different issues, for trade facilitation the two sets of standards need to be complementary because both potentially apply to all 
internationally traded foodstuffs derived from animals. These standards are founded on the common principle of risk (hazard) management (itself based on risk analysis) but the two organisations recommend different mechanisms for risk management. OIE standards, as already indicated, are predominantly geographic and apply mainly to live animals and basic commodities such as meat and milk. Codex Alimentarius standards, conversely, are nongeographic and founded exclusively on management of risk posed by specific products destined for human consumption using HACCP (hazard analysis critical control points) as the mechanism (www.codexalimentarius.org/input/download/standards/.../CPX_001e.pdf). Consequently the approaches applied to risk management for food safety and potential animal disease spread by food products are difficult to integrate even though the issues they address are technically generic (Thomson et al., 2004; Thomson et al., 2009; Rich and Perry, 2011). It needs to be acknowledged that the OIE interacts with the Codex Alimentarius Commission and other bodies such as the Global Food Safety Initiative (GFSI) to ensure harmonisation as far as possible but OIE standards remain predominantly geographically based. The need for such integration is exemplified by the approach of the European Commission to its Food Law; Regulation EC/178/2002 explicitly espouses adoption of integrated risk management along the production/value chain (i.e. the 'farm to fork' approach). The same central theme of 'safe, sustainable agricultural production worldwide' is based on value chain management adopted by GlobalGAP, a widely adopted private standard for good agricultural practice (www.globalgap.org/uk en). The FAO has recently contributed to this process by provided guidelines for risk management of animal diseases along value chains (FAO, 2011).

To counter the difficulties resulting from an exclusively geographic approach, the OIE has begun to introduce standards that are not entirely geographic, viz. 'compartmentalisation' and 'commodity-based trade' (CBT; sometimes referred to as commodity-specific standardization). An official definition for CBT is so far unavailable ${ }^{9}$ but the concept has been described (OIE, 2012b; Thomson et al., 2004; Thomson et al., 2009). A CBT approach to facilitate trade in aquatic animal commodities from areas not declared free of or possibly infected with specific diseases is in the process of development by the OIE (Oidtmann et al., 2012), with a view to facilitating 'safe' market access which they indicate can be especially helpful for developing countries. A particularly positive development in respect of beef trade was the introduction of a standard (Article 8.5.25 of the TAHC) which is partially based on the fact that deboning and removal of lymph nodes from beef renders it a 'very safe' product irrespective of the FMD-status of the locality of production (Thomson et al., 2009; Paton et

\footnotetext{
${ }^{9}$ A working definition used by the authors is: An array of alternatives that can be used individually or in combination to ensure that the production and processing of a particular commodity or product are managed so that identified food safety and animal health hazards are reduced to appropriate risk levels
} 
al., 2010). There are initiatives currently in progress to have this Article adopted as a regional standard for the SADC region. That would improve the prospects for regional beef trade substantially. However, there are three factors which complicate the issue:

- Article 8.5.25 does not yet appear to have gained wide acceptance among official veterinary services either within or outside SADC;

- The standard is partially geographic (requiring that FMD has not occurred within 10 $\mathrm{km}$ of the 'establishment' from which the animals originate in the last 30 days) which creates a major problem where wildlife are present in the general locality (see below);

- There is no independent accreditation mechanism like that provided for countries or zones free from FMD by the OIE.

The aptness or otherwise of the various clauses of Article 8.5.25 are summarised in Table 1. As indicated above a problem concerns the requirement for FMD not being present within a radius of $10 \mathrm{~km}$ of the 'establishment' from which the animals were derived within the last 30 days (1.d - Table 1) because FMD occurrence is defined in the TAHC chapter on FMD (8.5) as applying to both clinically diseased and subclinically infected animals. This means that simple physical inspection of animals, whether wild or domestic, is inadequate as a surveillance mechanism to detect the presence of FMD viruses. Absence of FMD as defined by articles in Chapter 8.5 of the TAHC dealing with surveillance is reliant in the case of possible subclinical infection on laboratory testing for antibodies induced by infection, presence of the viral genome in tissues of animals suspected of being infected (by PCR testing or other molecular techniques) or viral isolation (OIE, 2012c). Certification of this requirement, particularly in respect of wildlife, would be logistically and economically impossible in most locations in southern Africa where wildlife are abundant and therefore any such certificate would be suspect. It needs to be appreciated that in African buffalo subclinical infection is usual and is also common in other wildlife species (Thomson et al., 2003; Vosloo et al., 2009). Presumably clause 8.5.25.1d is an oversight and 'FMD' in this context is intended to refer to clinical signs consistent with FMD. If that is so, the relevant clause requires clarification. If not, the clause renders the application of this standard impractical in locations in or close to TFCAs.

For certain other diseases where wildlife is known to be significant in maintenance of the infection (e.g. NCD, avian influenza and classical swine fever) this problem has been dealt with by excluding wildlife species from consideration when it comes to trade in poultry meat 
Semi-quantitative assessment of the features of different risk management mechanisms associated with trade in commodities and products derived from animals (viewed from the perspective of FMD control)

\begin{tabular}{|c|c|c|c|c|c|c|c|}
\hline \multirow{2}{*}{ Method } & \multirow{2}{*}{$\begin{array}{l}\text { Benefits/ costs } \\
\text { focused on } \\
\text { participants in } \\
\text { livestock trade }\end{array}$} & \multirow{2}{*}{$\begin{array}{l}\text { Potential for } \\
\text { significant } \\
\text { adverse socio- } \\
\text { economic \& } \\
\text { environmental } \\
\text { impact }\end{array}$} & \multicolumn{2}{|c|}{$\begin{array}{c}\text { Requirement for } \\
\text { significant investment }\end{array}$} & \multirow{2}{*}{$\begin{array}{l}\text { Complements } \\
\text { complex } \\
\text { processing }\end{array}$} & \multirow{2}{*}{$\begin{array}{c}\text { Amenable to } \\
\text { routine } \\
\text { auditing }\end{array}$} & \multirow{2}{*}{$\begin{array}{c}\text { Promotion of } \\
\text { product } \\
\text { traceability }\end{array}$} \\
\hline & & & $\begin{array}{l}\text { Public } \\
\text { sector }\end{array}$ & $\begin{array}{l}\text { Private } \\
\text { sector }\end{array}$ & & & \\
\hline HACCP (CA) & +++ & - & + & +++ & +++ & +++ & +++ \\
\hline $\begin{array}{l}\text { Compartmental- } \\
\text { isation (TAHC) }\end{array}$ & +++ & + & + & +++ & ++ & ++ & ++ \\
\hline $\begin{array}{l}\text { Country- or } \\
\text { zonal freedom } \\
\text { from infection } \\
\text { (TAHC) }\end{array}$ & + & +++ & +++ & ++ & - & - & + \\
\hline
\end{tabular}

CA - Codex Alimentarius

TAHC - Terrestrial Animal Health Code

HACCP - hazard analysis, critical control points

CBT - commodity-based trade

CCP - critical control points
- - no effect

+ - little effect

++ - intermediate effect

+++ - marked effect 
and pork (OIE, 2012d-f). The justification for adopting a different principle in relation to FMD and some other diseases such as ASF is therefore unclear.

Standards associated with compartmentalisation likewise present difficulties for application in extensive livestock management systems associated with TFCAs because:

- Common/integrated bio-security security systems are difficult to apply effectively where multiple owners participate (in and around TFCAs there are many poor cattle owners mostly with fewer than 10 animals each and epidemiological units tend to be based on dip-tanks, 'cattle crushes' or villages rather than individual farms);

- The relevant TAHC article (8.5.6) proscribes vaccination within compartments created for FMD and also precludes the introduction of cattle that were vaccinated within the last 12 months into those compartments.

Conventionally, in the locations of southern Africa where FMD is endemic in wildlife, all cattle in and around such areas are vaccinated routinely against FMD at 6-monthly intervals or more frequently if the current manufacturer's recommendations are complied with (Thomson and Bastos, 2004; package insert for FMD vaccine produced by Botswana Vaccine Institute, http://www.bvi.co.bw/products/AFTOVAX.html, accessed 13 February 2013). It can be argued that vaccination of cattle in these areas provides added insurance that they will not transmit FMD virus and compartments free from FMD 'with vaccination' could be accepted in the same way as zones free with vaccination.

\section{The issue of competitiveness of the SADC region in international livestock trade}

In 2010 the value of global beef exports was about US \$ 6.6 billion with high world prices prevailing in 2010-11 due to strong growth in demand among advanced developing economies (FAOSTAT, 2012; Agritrade, 2012). Mapping of major beef trade flows attests to southern Africa's involvement in this trade being insignificant, i.e. only approximately $0.34 \%$ in 2010, although that percentage represents an increase of almost $50 \%$ on 2009 (FAOSTAT, 2012). This share of trade is even lower than might be expected bearing in mind that southern Africa produced 1.5\% of the world's beef in 2010 (FAOSTAT, 2012). Nevertheless, SADC countries contributed $80 \%$ of Africa's share to global beef exports.

Southern Africa's two major beef exporters (Botswana and Namibia) have performed poorly in recent years, continuing a decline that has been obvious for some time; reduction in export volumes to EU markets between $2010-2011$ amounted to $-93.3 \%$ and $-35.8 \%$ respectively (Agritrade, 2012; World Bank, 2012). Causes of this declining trade performance are complex but animal diseases and their trade effects were important factors; 
so were changes in the EU's Common Agricultural Policy, which reduced the value of beef sector trade preferences, stricter application of sanitary controls in the EU and rising global beef prices (Rich, 2009; Agritrade, 2012). Only Namibia among southern African countries has consistently maintained access to the EU market and generated a regular profit from that business in the last decade; Namibia's FMD-free zone has not experienced an outbreak since 1964. Rich and Perry (2011) have, furthermore, asserted that among southern African countries only Namibia enjoys a competitive advantage when it comes to livestock production. Nonetheless, production of beef in Namibia has declined since about 2005 and that decline is projected to continue (Potgieter, 2012; Lindsay et al., 2013). While chilled beef exports from Namibia had a 'revealed comparative advantage' (i.e. above 1) for the period between 2005 and 2011, that advantage has been declining steadily and, at the current rate, will fall to between one and zero before the end of this decade (Fig.4).

It needs to be borne in mind that currently beef exports from SADC countries such as Botswana and Namibia to the EU are duty- and quota-free in terms of provisional Economic Partnership Agreements (EPAs) negotiated between these countries and the European Commission (Rich and Perry, 2011). These EPAs need to be formally ratified by 2014 for market access advantages to continue, a process associated with a degree of political uncertainty (http://www.atf.org.na/news/). On the other hand, the Southern African Customs Union (SACU), of which Botswana and Namibia are members, applies $40 \%$ tariff protection to beef imports from non-SACU countries. So Botswana and Namibia enjoy bidirectional tariff advantages in respect of beef trade. It is openly acknowledged that without the tariff protection provided by provisional EPAs, neither Botswana nor Namibia would be price competitive in EU beef markets (P. Strydom, personal communication, 2011).

Livestock production systems within and in the vicinity of most TFCAs are currently traditional, i.e. not based on modern livestock farming practices although there are initiatives underway to modernise production methods, e.g. the Meat Board of Namibia/Livestock $\begin{array}{llll}\text { Producers } & \text { Forum } & \text { Mentorship }\end{array}$ (http://www.newera.com.na/articles/43710/mentorship-programme-should-bear-fruit). As is the case in most traditional systems off-take is low (Table 2), and the quality of cattle marketed for slaughter and subsequent beef production does not accord with the demands of high-value international markets owing to animals being relatively old and small in size $(P$. Strydom, personal communication, 2011; Potgieter, P., 2012; Naziri et al., in press). Nevertheless, if for a start off-take could be improved even slightly, a marked positive impact on income generation in the Northern Communal Areas of Namibia, for example, would result (Table 2). 
Table 2: Actual off-take of cattle from the Northern Communal Area (NCA) of Namibia and value thereof in 2010 compared with additional value that could be obtained by increasing off-take (P. Strydom, 2011, table presented at SADC Livestock Technical Committee Meeting, 3-5 November 2011, Gaborone, Botswana)

\begin{tabular}{|l|c|c|c|c|c|}
\hline \multirow{2}{*}{ Off-take } & Actual & $\mathbf{1 . 2 3} \%$ & \multicolumn{2}{|l|}{} \\
\cline { 2 - 6 } & Projected & - & $\mathbf{3 \%}$ & $\mathbf{7 \%}$ & $\mathbf{2 5 \%}$ \\
\hline $\begin{array}{l}\text { No of cattle marketed } \\
\text { (Cattle population = } \\
1245 \text { 764) }\end{array}$ & 15489 & 37373 & 87203 & 311411 \\
\hline Value (N\$ - millions) & 49.3 & 118.8 & 277.4 & 990.7 \\
\hline $\begin{array}{l}\text { Additional income that } \\
\text { would be achieved by } \\
\text { increased off-take (N\$ - } \\
\text { millions) }\end{array}$ & - & 69.6 & 228.1 & 941.4 \\
\hline
\end{tabular}

$\$($ US) $1=\operatorname{approx} 8 \mathrm{~N} \$($ November 2011) 


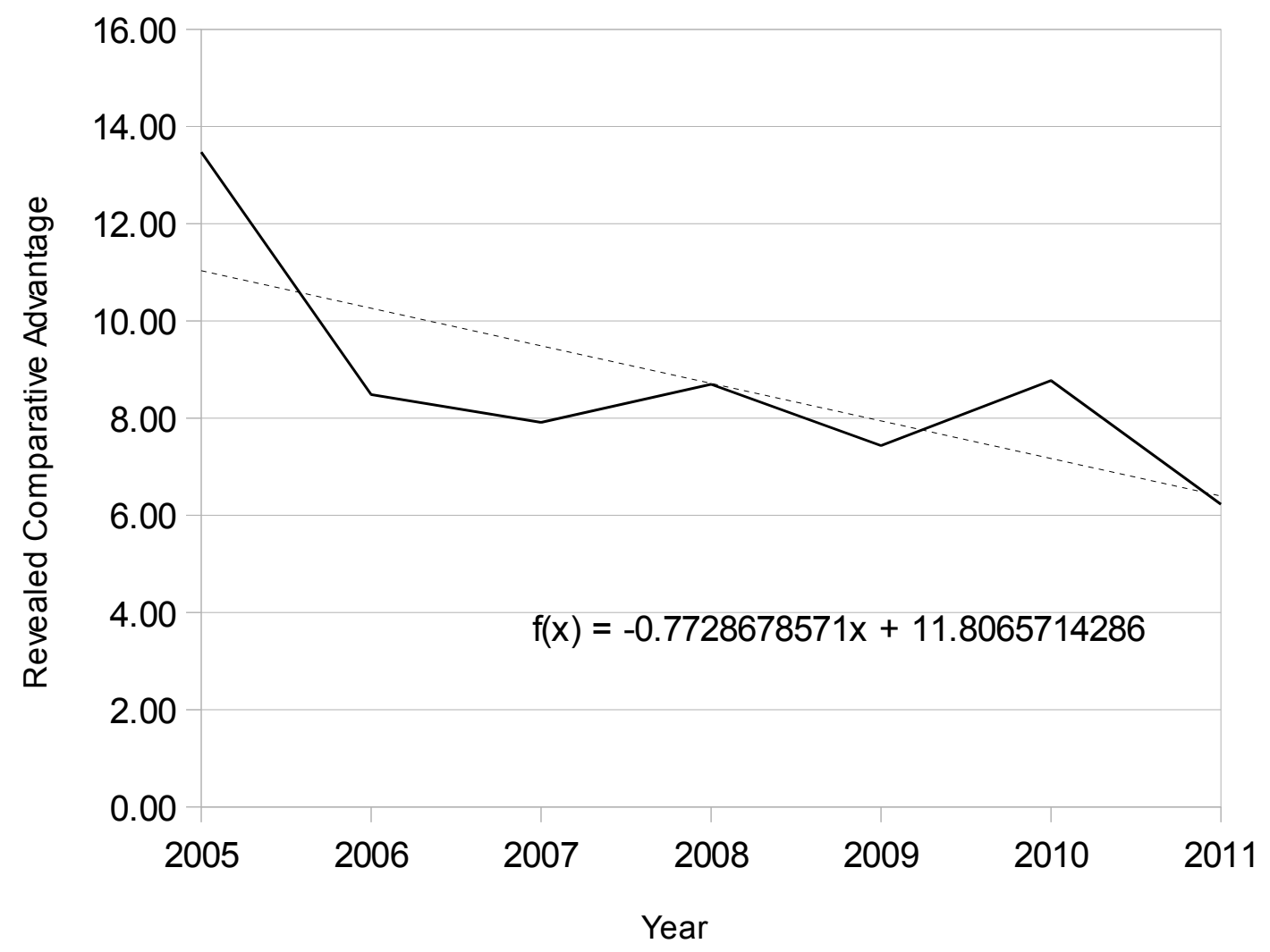

Figure 4

Revealed Comparative Advantage for chilled beef exports from Namibia 2005 to 2011 (Source: World Integrated Trade Solution [WITS] Database, http://wits.worldbank.org/WITS/FAQs.htm|\#Databases) 
It is consequently fair to conclude that beef production in southern Africa is currently uncompetitive in a global context. This is despite efforts over at least the last 50 years aimed at establishing export industries targeting high value beef markets dependent upon the creation of FMD-free zones in SADC countries, which in any case are proving increasingly ineffective (Fig. 2). Turning this situation around will require at least three changes in current circumstance:

- Refinement, acceptance, and application of sanitary trade standards that manage risk through non-geographic approaches;

- Strategies to broaden market access, in turn dependent upon improved management of TADs, especially those that can be maintained and spread by wildlife;

- Improvement in the competitiveness of livestock production in the SADC region facilitated by increased investment in animal production.

\section{Discussion}

Transboundary animal diseases and the control methods designed to limit their spread have, for many decades, significantly constrained both livestock agriculture and wildlife conservation in southern Africa. Encouragingly, the impacts of these disease control methods on wildlife conservation and the environment, particularly in southern Africa, are increasingly being recognised by policy makers. Furthermore, recent changes to international sanitary standards governing trade in animal commodities and products provide new opportunities for reconciling the conflicting interests of these two rural development imperatives. However, deficiencies in capacity and competitiveness when it comes to livestock production, allied with increasing incidence of diseases like FMD (Fig. 2), makes exploitation of these new opportunities problematic (Cabrera et al., 2008; Rich, 2009).

Establishment of FMD-free zones and negotiating access to foreign beef markets on that basis has hitherto been the only possible approach to overcoming the trade-limiting effects of FMD in southern Africa. However, establishment and maintenance of disease-free zones (DFZs), particularly in the vicinity of large TFCAs, presents a fundamental difficulty because DFZs and TFCAs are based on different principles: respectively the need to separate animal populations of different health status and the need to maintain connectivity between populations (Osofsky et al., 2005). From a practical perspective, some of the fencing systems considered necessary to enclose FMD-free zones have had unfortunate and well documented environmental consequences (Osofsky et al., 2005; Mbaiwa and Mbaiwa, 2006, Osofsky et al., 2008; Ferguson and Hanks, 2010). It was hitherto tacitly accepted that public 
expenditure on animal disease control and associated adverse environmental costs were compensated for by the benefits provided by international trade. Unfortunately, because the costs of policies aimed at trade-influencing diseases such as FMD are hard to disaggregate from national animal health budgets, this assumption is difficult to substantiate or refute. However, access to foreign markets by southern African countries through maintenance of FMD-free zones is proving increasingly problematic (Rich, 2009; Agritrade, 2012). Secondly, only a minority of livestock producers are located within FMD-free zones, rendering zoning systems socially, politically and financially discriminatory (Scoones et al., 2010). Thirdly, the value of wildlife in terms of nature-based tourism has reached a level of economic return that probably compares favourably or even exceeds income generated by livestock, although there is evidence that revenues from wildlife do not necessarily trickle down to local communities (Fernández et al., 2009, Tembo et al., 2009; Fernández, 2010). In the long run therefore, lack of practical alternatives to DFZs as currently predicated by provisions of the TAHC will continue to constrain rural development at the livestock/wildlife interface, especially in the TFCAs. More positively, simple and technically sound non-geographic trade standards could be used to overcome this problem (Thomson et al., submitted).

The importance of matching animal disease control policies with target markets was emphasised by Scoones et al. (2010), the point being that there is some latitude for adopting alternative approaches to animal disease management depending on the particular target market. However, in order to compete effectively in international markets many other factors need to be in place; the major elements are summarised in Fig. 5. Previous studies into the interactions between animal disease management, the economics of production and marketing and trade standards for commodities and products derived from animals have essentially ignored rival or even complementary land-use options, wildlife conservation in particular. In this context, the issue of wildlife and its conservation is integral to the rural development mix in southern Africa where there is growing realisation of the economic importance of wildlife conservation and other income sources associated with wildlife which are equally important for sustainable rural development. It can consequently no longer be implicitly accepted that livestock production should enjoy priority over biodiversity conservation and the various income streams that flow from it. Equally, however, biodiversity conservation cannot ignore the obvious fact that nature-based tourism, the major projected income generator needed to sustain biodiversity conservation in the SADC region, will not, on its own, enable rural populations to develop and escape the poverty trap adequately (Cumming and Atkinson, 2012). For that to happen, diversification of income generation in rural locations will be necessary. 


\section{PREREQUISITES FOR ALL SYSTEMS}

Infrastructure Sustainable productive capacity Entrepreneurship Market specific requirements Food safety compliance Competitive cost of production Traceability including animal ID

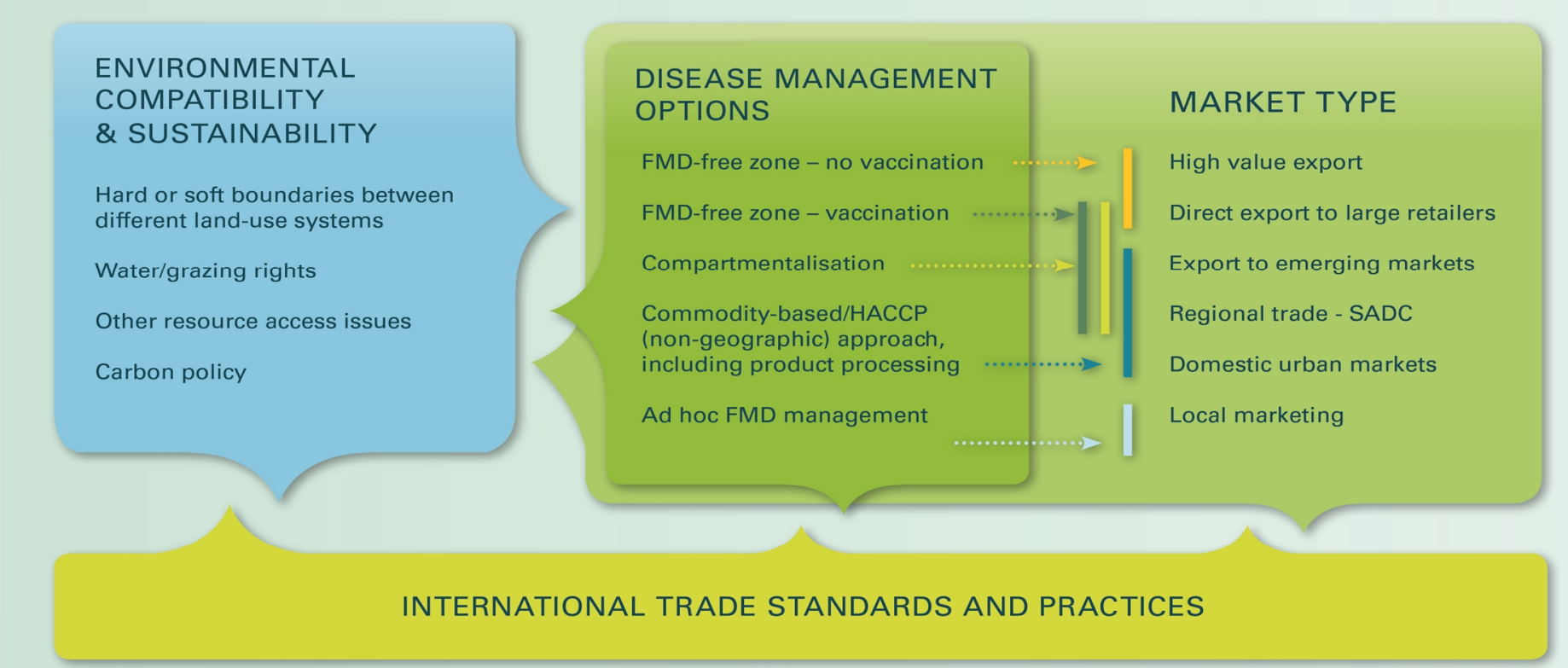

Fig. 5

Interacting factors that determine market access and competitiveness 
It has been pointed out that countries such as Argentina, Brazil and India are more likely to benefit from the introduction of non-geographic SPS trade standards than African countries (Rich and Perry, 2011). When it comes to competitiveness of livestock agriculture, southern African countries are at a serious disadvantage, not exclusively due to the presence of a number of trade-influencing TADs in the region. Lack of productive capacity (i.e. relatively small national herds) is a problem, as is organisation of the beef industries and marketing policies (Rich, 2009; Ransom, 2011). The result is that the two leading beef exporters in the region (Botswana and Namibia) have suffered significant declines in beef exports to the EU in the recent past. We argue, as have others, that the prime reason for this declining competitiveness is insufficient investment, particularly private sector investment, in productive capacity and efficiency (Cabrera et al., 2008). Investment, certainly from the private sector, will only occur if prospects for generating profitable returns improve significantly. That, in turn, is dependent on broader access to potentially profitable markets. For these reasons the implication that there is little point in worrying unduly about market access because even if that were provided, countries of the southern African region would be unable to compete effectively (Rich and Perry, 2011) is arguably incorrect. On the other hand, devoting a larger proportion of available resources to improvement of the efficiency of and capacity for livestock production, combined with non-geographic approaches to risk management associated with trade in animal commodities and products that do not require large-scale public investment in disease control programmes, has a rational basis.

It is well recognised that systems founded on the CBT concept are able to effectively manage animal disease hazards associated with international beef trade (Thomson et al., 2009; Paton et al., 2010); however, widespread adoption of such systems will require further refinement of product-specific sanitary standards, i.e. standards other than those based on the creation of large infection-free areas that result in detrimental environmental and social impacts (Ferguson and Hanks, 2010). Article 8.5.25 of the TAHC provides an example of a relatively new, mostly non-geographic, trade standard that at face value creates new opportunity for enabling international trade in deboned beef from areas within and close to TFCAs. However, this article is unlikely to provide the benefits intended unless at least one of the clauses is amended (Table 1). It is also unlikely to be widely applied and accepted unless it is seen by veterinary authorities in both exporting and importing countries as equivalent to the geographically-based standards and not as an inferior alternative, i.e. it needs to be understood that 'equivalence' means precisely that.

In reaction to the situation outlined above, it has been observed that (1) it probably does not make sense to attempt to produce beef for international export in southern Africa (i.e. the circumstances are simply not propitious), (2) other parts of the world also have problems 
related to competitiveness and sanitary standards, (3) southern African countries (i.e. members of SACU) apply their own tariff and non-tariff protectionist measures and, furthermore, do not trade effectively with each other and (4) that the rest of the world has no obligation to 'subsidise' or make special provision for southern Africa. There are elements of truth in all these assertions but that does not negate the fundamental issue of current trade standards related to trade in commodities and products derived from animals presenting a basic obstacle to wildlife/biodiversity conservation in one of the few remaining parts of the world with abundant free-living ungulates and associated predators in extensive wilderness areas, i.e. an irreplaceable global resource.

The need to balance biodiversity conservation and livestock production in southern (and many other locations in sub-Saharan) Africa is clear and increasingly accepted. However, progress in this respect will only be achieved if alternative, non-geographic trade standards become available and universally accepted at a faster rate than is currently the case. These new standards need to serve both commercial and traditional livestock farming interests and at the same time be compatible with the broad needs of biodiversity conservation.

\section{References}

Agritrade, 2012: Executive Brief Update: Beef Sector. Available at: http://agritrade.cta.int/Agriculture/Commodity/Beef/Executive-Brief-Update-2012-Beef-sector (accessed 2 March 2013). http://agritrade.cta.int/Agriculture/Commodities/Beef/ExecutiveBrief-Update-2012-Beef-sector

Alexander, D.J., J.G. Bell and R.G. Alders, 2004: Technology review: Newcastle Disease, with Special Emphasis on its Effect on Village Chickens. FAO Anim. Prod. Health Pap.161, FAO, Rome.

Barnes, J.I., 2013: Economic analysis of land0use policies for livestock, wildlife and disease management in the Caprivi, Namibia, with potential wider implications for regional transfronteir conservation areas. Technical report to the Wildlife Conservation Society's AHEAD Program and the World Wildlife Fund. 84pp.

Bengis, R.G., R.A. Kock, G.R. Thomson and R.D. Bigalke, 2004: Infectious diseases of animals in sub-Saharan Africa: The livestock/wildlife interface. In: Coetzer, J.A.W. and R.C. Tustin (eds), Infectious Diseases of Livestock, $2^{\text {nd }}$ edn, vol. 1. pp. 225-238. Oxford University Press, Cape Town, South Africa.

Cassidy, D, Thomson, G. \& Barnes, I., 2013: Establishing priorities through use of multicriteria decision analysis for a commodity based trade approach to beef exports from the East caprivi region of Namibia. USAID, Southern Africa, 109pp.

Cabrera, R., M. Cochran, L. Danglemayr, G. D'Aguilar, K. Gwande, J. Lee, I. Spier and C. Weigand, 2008: African capacity building for meat exports: Lessons from the Namibian and 
Botswanan beef industries. Draft working paper No 596. George H. W. Bush School of Government and Public Service, Texas A\&M University, College Station, USA.

Chase, M., 2009: Fixed-wing aerial wildlife census of the Caprivi river systems: A survey of the rivers, wetlands and flood plains, September 2009. Namibian Government, Namibia Wildlife Foundation and WWF, Windhoek, Namibia.

Chiriboga, L.M., C. Kilmer, R. Fan and K. Gwande, (undated): Does Namibia have a comparative advantage in beef production? George H W Bush School of Government and Public Service, Texas A\&M University, College Station, USA.

Coetzer, J.A.W. and R.C. Tustin, (eds), 2004: Infectious Diseases of Livestock, $2^{\text {nd }}$ edn, Vols 1 and 2. Oxford University Press, Cape Town, South Africa.

Crispo, E., J.-S. Moore, J. Lee-Yaw, S.M. Gray and B.C. Haller, 2011: Broken barriers: Human-induced changes to gene flow and introgression in animals. Bioessays 33, 508 518.

Cumming, D.H.M., 2008: Large Scale Conservation Planning and Priorities for the KavangoZambezi Transfrontier Conservation Area, Conservation International. Available at: http://www.wcs-ahead.org/kaza/kaza tfca large scale planning final 7nov08 logo.pdf (accessed 2 March 2013).

Cumming, D.H.M., 2011. Constraints to conservation and development success at the wildlife-livestock-human interface in Southern African Transfrontier Conservation Areas: A Preliminary Review. Report to the Wildlife Conservation Society (WCS). Available at: http://www.wcs-ahead.org/kaza/constraints to cons \& dev success 082311.pdf (accessed 3 March 2013).

Cumming, D.H.M. and M.W. Atkinson, 2012: Land-use paradigms, wildlife and livestock: Southern African challenges, choices and potential ways forward. In: Karesh, W. and C. Machalaba (eds), Animal Health and Biodiversity: Preparing for the Future. Compendium of the OIE Global Conference on Wildlife, 23-25 February, 2011, pp. 101 - 112. World Organisation for Animal Health (OIE), Paris, France.

Cumming, G.S., A. Caron, C. Abolnik, G. Cattoli, L.W. Bruinzeel, C.E. Burger, K. Cechettin, N. Chiweshi, B. Mochotlhoane, G.L. Mutumi and M. Ndlovu, 2011: The ecology of influenza A viruses in wild birds in southern Africa. EcoHealth 8, 4-13.

European Commission, Directorate F, 2011: Final Report on the Audit carried out in Botswana from 25 to 28 January 2011. DG (Sanco) 2011-6119-MR FINAL. Reference: Ares(2011)549165-20/05/2011. Available http://ec.europa.eu/food/fvo/act getPDF.cfm?PDF ID=8894 (accessed 3 March 2013).

FAO, 2011: A Value Chain Approach to Animal Diseases Risk Management - Technical Foundations and Practical Framework for Application. Anim. Prod. Health Guidelines, No. 4, FAO, Rome.

FAOSTAT, 2012: Livestock primary. Available at: http://faostat.fao.org/site/569/default.aspx\#ancor (accessed 23 April 2013).

Ferguson, K. and J. Hanks, (eds), 2010: Fencing Impacts: A Review of the Environmental, Social and Economic Impacts of Game and Veterinary Fencing in Africa with Particular Reference to the Great Limpopo and Kavango-Zambezi Transfrontier Conservation Areas. Mammal Research Institute, University of Pretoria, Pretoria, South Africa. 
Fernández, A., 2010: Wildlife conservation in Zambia - Impact of game management areas on household welfare. MSc Thesis, Michigan State University.

Fernández, A., R.B. Richardson, D. Tschirley and G. Tembo, 2009: The impacts of wildlife conservation policies on rural household welfare in Zambia. Policy Synthesis, Food Security Research Project - Zambia Ministry of Agriculture and Cooperatives, Agricultural Consultative Forum and Michigan State University No 33. Available at: http://fsg.afre.msu.edu/zambia/ps33.pdf (accessed 8 May 2013).

Gauthier-Clerc, M., C. Lebarbenchon and F. Thomas, 2007: Recent expansion of highly pathogenic avian influenza H5N1: a critical review. Ibis 149, $202-214$.

Heffernan, C., 2009: Panzootics and the poor: devising a global livestock disease prioritisation framework for poverty alleviation. Rev. Sci. Tech. 28, $897-907$.

Lindsay, P.A., C.P. Havemann, R.M. Lines, A.E. Price, T.A. Retief, T. Rhebergen, C. Van der Waal and S.S. Romañach, 2013: Benefits of wildlife-based land uses on private lands in Namibia and limitations affecting their development. Oryx 47, 41-53.

Mbaiwa, J.E. and O.I. Mbaiwa, 2006: The effects of veterinary fences on wildlife populations in Okavango Delta, Botswana. Int. J. Wilderness 12, $17-23,41$. Available at: http://www.ubrisa.ub.bw:8080/bitstream/handle/10311/28/mbaiwa int j wilderness 2006.pd

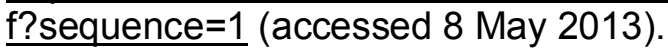

Naziri, D., K.M. Rich, and B. Bennett, in press. Would a commodity-based trade approach improve market access for Africa? A case study of the potential of beef exports from communal areas of Namibia. Dev. Pol. Rev.

Oidtmann, B., C. Johnston, K. Klotins, G. Mylrea, P.T. Van, S. Cabot, P. Rosado Martin, L. Ababouche and F. Berthe, 2012: Assessment of the safety of aquatic animal commodities for international trade: the OIE Aquatic Animal Health Code, Transb. Emerg. Dis. 60, 27 38.

OIE, 2012a: Terrestrial Animal Health Code, Chapter 4.3. Zoning and Compartmentalisation. Available at: $\quad$ http://www.oie.int/index.php?id=169\&L=0\&htmfile=chapitre 1.4.3.htm (accessed 3 March 2013).

OIE, 2012b: Health Standards: Commodity-based Approach. Available at: http://www.oie.int/international-standard-setting/overview/commodity-based-approach/ (accessed 3 March 2013).

OIE, 2012c: Terrestrial Animal Health Code, Chapter 8.5. Foot and Mouth Disease. Available at: http://web.oie.int/eng/normes/mcode/en chapitre 1.8.5.htm (accessed 3 March 2013).

OIE, 2012d: Terrestrial Animal Health Code, Chapter 10.4. Infection with Viruses of Notifiable Avian Influenza. Available at: http://www.oie.int/index.php?id=169\&L=0\&htmfile=chapitre 1.10.4.htm (accessed 3 March 2013)

OIE, 2012e: Terrestrial Animal Health Code, Chapter 10.9. Newcastle Disease. Available at: http://www.oie.int/index.php?id=169\&L=0\&htmfile=chapitre 1.10.9.htm (accessed 3 March 2013) 
OIE, 2012f: Terrestrial Animal Health Code, Chapter 15.2. Classical swine fever. Available at: $\quad$ http://www.oie.int/index.php?id=169\&L=0\&htmfile=chapitre 1.15.2.htm $\quad$ (accessed 3 March 2013).

Osofsky, S. A., S. Cleaveland, W. B. Karesh, M. D. Kock, P. J. Nyhus, L. Starr and A. Yang, (eds), 2005: Conservation and Development Interventions at the Wildlife/Livestock Interface: Implications for Wildlife, Livestock and Human Health. IUCN, Gland, Switzerland and Cambridge, United Kingdom. Available at: http://www.wcs-ahead.org/wpc launch.html (accessed 8 May 2013). http://www.wcs-ahead.org/book/AHEADbook6.5MB.pdf (accessed 28 July 2013)

Osofsky, S. A., D. H. M. Cumming and M. D. Kock, 2008: Transboundary Management of Natural Resources and the Importance of a 'One Health' Approach: Perspectives on Southern Africa. In: Fearn, E. and K. H. Redford (eds), State of the Wild 2008-2009: A Global Portrait of Wildlife, Wildlands, and Oceans, pp. 89-98. Island Press, Washington D.C., USA. Available at: http://www.wcs-ahead.org/print.html; http://www.wcsahead.org/documents/transbound sotw.pdf (accessed 8 May 2013).

Paton, D.J., M. Sinclair and R. Rodríguez, 2010: Quantitative assessment of the commodity risk for spread of foot-and-mouth disease associated with international trade in deboned beef. Transb. Emerg. Dis. 57, 115-134.

Penrith, M-L. and G.R. Thomson, 2012: Analysis of the Status of Transboundary Animal Diseases and their Control in the SADC Region During the Period 2005 - 2011, Focusing on the Five Countries that contribute Land to the Kavango-Zambesi (KAZA) Transfrontier Conservation Area (TFCA). Report to the Wildlife Conservation Society's AHEAD Program. Available at: http://www.wcs-ahead.org/workinggrps kaza.html (accessed 20 June 2012).

Potgieter, P., 2012: Joint Vision for the Namibian Meat Industry. Power point presentation to the Livestock Producer's Organisation Congress, 8 October 2012, Windhoek, Namibia. Available at http://www.agrinamibia.com/index.php?module=downloads (accessed 8 May 2013).

Ransom, E., 2011: Botswana's beef global commodity chain: Explaining the resistance to change. J. Rural Stud. 27, 431-439.

Rich, K. M., 2009: What can Africa contribute to global meat demand? Opportunities and constraints. Outlook on Agriculture 38, 223-233.

Rich, K.M. and B.D. Perry, 2011: Whither commodity-based trade? Dev. Pol. Rev. 29, 331357.

Roe, D., D. Thomas, J. Smith, M.D. Walpole and J. Elliott, 2011: Biodiversity and poverty: Ten frequently asked questions - ten policy implications. Gatekeeper 150, July 2011. International Institute for Environment and Development. Available at: http://pubs.iied.org/14612IIED.html (accessed 8 May 2013).

SADC/EU/USAID, 2008: Achieving compatibility between the transfrontier conservation area (TFCA) concept and international standards for the management of transboundary animal diseases (TADs). Report of the workshop held at the Chobe Marina Lodge, Kasane, Botswana, 11-14 November 2008. Available at: http://www.wcsahead.org/documents/sadc tfcas tads nov08.pdf (accessed 22 December 2010).

Scholes, R.J. and R. Biggs (eds), 2004: Ecosystem Services in Southern Africa: A Regional Assessment. Council for Scientific and Industrial Research, Pretoria, South Africa. 
Scoones, I., A. Bishi, N. Mapitse, R. Moerane, M-L. Penrith, R. Sibanda, G. Thomson and W. Wolmer, 2010: Foot-and-mouth disease and market access: Challenges for the beef industry in southern Africa. Pastoralism 1, 135-164.

Tembo, G, S. Bandyopadhyay and J-M. Pavy, 2009: Impact of natural resource conservation policies on household consumption around Zambian national parks. Policy Synthesis, Food Security Research Project - Zambia Ministry of Agriculture and Cooperatives, Agricultural Consultative Forum and Michigan State University No 35 http://fsg.afre.msu.edu/zambia/ps35.pdf (accessed 8 May 2013).

Thomson, G.R., W. Vosloo and A.D.S. Bastos, 2003: Foot and mouth disease in wildlife. Virus Res. 91, 145-161.

Thomson, G.R. and A.D.S. Bastos, 2004: Foot and mouth disease. In: Coetzer, J.A.W. and R.C. Tustin (eds), Infectious Diseases of Livestock, $2^{\text {nd }}$ edn, pp. 1324-1365. Oxford University Press, Cape Town, South Africa.

Thomson, G.R., E.N. Tambi, S.K. Hargreaves, T.J. Leyland, A.P. Catley, G.G.M. van 't Klooster and M-L. Penrith, 2004: International trade in livestock and livestock products: The need for a commodity-based approach. Vet. Rec. 155, 429-433.

Thomson, G.R., T.J. Leyland and A.I. Donaldson, 2009: De-boned beef - an example of a commodity for which specific standards could be developed to ensure an appropriate level of protection for international trade. Transb. Emerg. Dis. 56, 9-17.

Thornton, P.K., R.L. Kruska, N. Henninger, P.M. Kristjanson, R.S. Reid, F. Atieno, A.N. Odero and T. Ndegwa, 2002: Mapping Poverty and Livestock in the Developing World. International Livestock Research Institute, Nairobi, Kenya.

UNEP, 2011. African Environmental Outlook: Past, Present and Future Perspectives. http://www.unep.org/dewa/africa/publications/aeo-1/ (accessed 8 May 2013).

University of Pretoria/Agricultural Research Council, 2011: Southern African Foot-and-Mouth Disease Bulletin, Edition 3. Available at: http://www.foot-and-mouth.org/opendocuments/bulletin-fmdsa-back-issues/SSFB3.pdf/view (accessed 8 May 2013).

Vosloo, W., P.N. Thompson, B. Botha, R.G. Bengis and G.R. Thomson, 2009: Longitudinal study to investigate the role of impala (Aepyceros melampus) in foot-and-mouth disease maintenance in the Kruger National Park, South Africa. Transb. Emerg. Dis. 56, 18-30.

World Bank, 2012. Botswana Development Policy Review: An agenda for competitiveness and diversification. $\quad$ http://documents.worldbank.org/curated/en/2012/09/17671934/botswanadevelopment-policy-review-agenda-competitiveness-diversification $\quad$ (accessed 15 May 2013). 